\title{
『Nature Photonics』創刊
}

\section{Enter Nature Photonics}

Nature Vol.445 (2) / 4 January 2007

光の研究とその応用に取り組むフォトニクスの分野は、こ の 50 年の間に現代の最重要実現技術の 1 つにまで成長 した。レーザー、発光ダイオード、低損失光ファイバー、 $\mathrm{CCD}$ (電荷結合素子) 検出器などのデバイスの開発は世の 中を一変させ、デー夕通信、材料加工、画像処理、生物医 学、照明、ホームエンターテインメントなどへの応用も著 しい進歩を遂げている。

フォトニクスの基礎研究は、それ自体が非常に興味深い だけでなく、さらなる転換技術へとつながっていく。例え ば、負の屈折率をもつ人工材料の創出は、最先端の集学的 研究であるのみならず、より高い解像度での光検出と光加 工を可能にすることが期待されている。また、「フォトニッ ク結晶」に光子を捕捉するエンジニアリング材料は新しい タイプの光メモリの開発につながることが期待されている し、シリコン系全光回路が開発されれば通信や計算の分野 が一変すると予想されている。

フォトニクスの活況と重要性とを考えると、この分野の ジャーナル誌が果たすべき役割は非常に大きい。ジャーナ ル誌は、すぐれた研究成果だけでなく、技術開発とそれが もたらす影響を、商品開発まで含めて把握し、この分野に 強い関心を寄せているあらゆる読者に向けて発信するもの でなければならない。その思いで 2007 年 1 月に創刊した のが Nature Photonics（www.nature.com/nphoton 参照） であり、創刊号には上記のテーマを含む広範な記事が掲載 されている。

Nature 本誌は、今後もインパクトの大きいフォトニクス 関連論文を揭載していく。すでに発刊されている Nature Physics、Nature Materials、Nature Nanotechnologyなどの リサーチ誌も、各分野における Nature の役割を薄めるこ となく、質の高い研究成果を発表したり、それについて議 論したりするための新しい場を提供してきた。
出版事業の点から見た Nature Photonicsには、編集本 部を東京に置く(ただし、ロンドンおよびサンフランシス コにアソシエートエディターがいる）初めての Nature 系 ジャーナル誌という独自性がある。これにより、フォトニ クスの分野で特に大きな存在感を示しているアジア太平洋 地域の研究者たちと編集部との結びつきがさらに強まるこ とだろう。もちろん、Nature Photonicsは、ほかのすべて の Nature 系ジャーナル誌と同じく、真の国際ジャーナル であり、特定の地域を優先することなく、全世界の研究論 文を揭載していくものである。

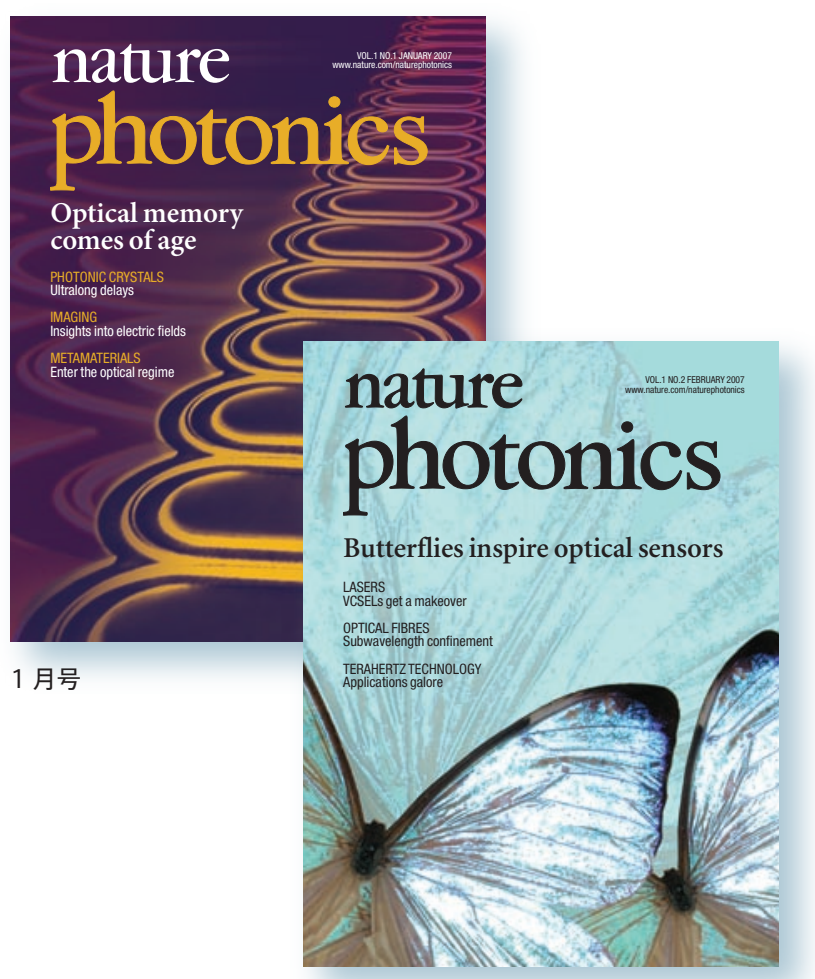

2 月号 